\title{
sciendo
}

\section{The Assessment of Expert Evidence on DNA in Malaysia}

\author{
Ramalinggam Rajamanickam ${ }^{1}$ \\ Mohd Safri Mohammed Na'aim² \\ Tengku Noor Azira Tengku Zainudin ${ }^{1}$ \\ Zainunnisaa Abd. Rahman ${ }^{1}$ \\ Mohd Zamre Mohd Zahir ${ }^{1}$ \\ Muhammad Hatta ${ }^{3}$ \\ ${ }^{1}$ Faculty of Law, Universiti Kebangsaan Malaysia (UKM), Malaysia \\ ${ }^{2}$ Faculty of Law, Universiti Teknologi MARA (UiTM), Malaysia \\ ${ }^{3}$ Department of Criminal Law, Universitas Malikussaleh, Aceh, Indonesia
}

Doi: 10.2478/ajis-2019-0016

\section{Abstract}

One of the most common forms of evidence used by the Public Prosecutor in a courtroom to prove a case is DNA evidence. The DNA evidence process started when the police collected the physical evidence relevant to the alleged offence at the crime scene. The collected evidence will then usually be sent to the Department of Chemistry Malaysia for DNA analysis. The chemist will extract the DNA from the relevant physical evidence by using specific techniques. The outcome of the analysis will be used to complete the investigation of the case. Being an independent organization, the Chemistry Department strives to provide impartial forensic science analysis. Thus, from the analysis, sometimes DNA evidence does not necessarily implicate the accused with the alleged offence but may also disclose the involvement of a third party in the alleged offence that may cast doubt on the prosecution's case. This can be seen in the Federal Court's case of Public Prosecutor v Hanif Basree Abdul Rahman [2008] 4 CLJ 1. The evidence will then be presented by the prosecution before the court to assist judges in making the right decisions. This indicates the important role played by an expert in the court decision making process. In this context, questions always arise as to the probative value of DNA evidence given by experts in the courtroom. Can the court convict a person solely on DNA evidence? This article focuses on the position of DNA experts in Malaysia under section 45 of the Evidence Act 1950. It was found that although the DNA evidence is given by the experts, the probative value depends on the nature of the evidence itself.

Keywords: DNA evidence; Evidence Act 1950; expert evidence; probative value

\section{Introduction}

DNA analysis is one of the most common evidence presented in judicial proceedings (Gupta et al. 2016). DNA stands for deoxyribonucleic acid i.e. a patterned chemical structure of genetic information (Garner 2014). According to Black's Law Dictionary, DNA identification is a method of scientific identification based on a person's unique genetic makeup (Garner 2014). DNA is extracted from the physical samples found in a case (Magalhães et al. 2015). The DNA samples collected will be analysed by way of comparison to match the samples collected by qualified 
experts with the DNA profiles of known suspects (Matheson 2016). In criminal cases, physical samples which are collected from the crime scene play a pivotal role in the investigation and resolution of cases (Shaler 2011). This is because DNA analysis can assist the relevant authorities in identifying suspects, victims, and also in exonerating the innocent (Bowers 2014). According to Oxford's Dictionary of Law, DNA fingerprinting is a scientific technique in which an individual's genetic material (DNA) is extracted from cells in a tissue sample and analysed to produce a graphic chart that is unique to that person. The technique is used as evidence of identity in a criminal or civil case and has been notably successful in both paternity and rape cases (Martin 1994).

\section{Material and Method}

A qualitative approach was used for this research consisting of a detailed analysis of the Evidence Act 1950 , cases and scholarly writings related to this area. This research adopted a content analysis method for analysing existing DNA-related provisions and cases to identify and examine the position of DNA evidence in the Malaysian courtroom. The relevant provisions and cases in the Malaysian Evidence Act 1950 are critically analyzed in order to get a sound finding (Ramalinggam Rajamanickam et al. 2015).

\section{Background}

When a case proceeds with a trial, witnesses may be called to testify in court (Wheatcroft \& Ellison, 2012). Witnesses may be called by the Public Prosecutor to prove its case against the accused. On the other hand, accused may call witness to give evidence in court to prove his innocence. Hence, witnesses play an important role in criminal justice system. In general, witnesses may be categorised into two: which are witnesses of fact and witnesses of opinion (Noraini, 2007). Witnesses of fact are witnesses who testify in court in regard to evidence based on what they observed, heard and perceived (known as direct evidence) as embodied in section 60(1)(a) - (c) of the Evidence Act 1950. Evidence of opinion is usually inadmissible, but there is an exception when an expert is the person giving his opinion. Opinion evidence is evidence in the form of an inference or a conclusion (Ingram, 2017). The expertise may be obtained by experts through academic qualifications, experience, skills and professional training (Fisher, 2017). They are experts in their subject matter that the ordinary people may not know. Thus, expert evidence is important to assist the court to make a right decision (Ramalinggam \& Anita 2014). Realising the importance of experts, section 45 of the Evidence Act 1950 permits the experts to give evidence in court based on their opinions over specific subject matter. However, in light of the section, it is important to note that the court can only obtain the assistance of experts in the fields described in the section. The fields are: foreign law; science or art; handwriting; and finger impression. Conversely, experts from other fields who are not listed in this section cannot be called to give evidence (Ramalinggam, 2017). Thus, in order to allow DNA experts to testify in any case, they must come from the fields provided for in section 45 of the Evidence Act. In light of Chandrasekaran \& Ors v PP [1971] 1 MLJ 153 p.159 and Pathmanabhan Nalliannen v Public Prosecutor \& Other Appeals [2017] 4 CLJ 137 p.178, DNA fall under the field of science, thus such evidence is relevant in court. DNA evidence is important to identify a person's identity (Dedrickson 2017). Without it, the identification process becomes difficult and to some extent impossible, especially if the prosecution has no other evidence (Hunter 2010). Therefore, if the prosecution's case is mainly based on DNA evidence, such evidence is crucial to prove or disprove any facts. Despite its relevancy in court, the next question is whether or not the court is bound by expert evidence is another matter to be considered. This is because in general, expert evidence can be divided into two forms which are non-scientific evidence and scientific evidence (Morsek 2000). The answer to this question will be explained below.

\section{Admissibility of DNA Evidence}

In the context of the admissibility of DNA evidence, there are some underlying principles that need to be understood. 


\subsection{Relevancy of DNA Evidence}

The basic principle of common law evidence is only relevant evidence is admissible in the court. Now, the question is what is the meaning of relevant evidence? In Malaysia, relevant evidence is evidence that falls within the ambit of section 6 to section 55 of the Evidence Act 1950. If the DNA evidence is relevant under any of the provisions, then such evidence will be admitted by the court. This is known as the prima facie rule.

DNA evidence is relevant under two main provisions under the Evidence Act 1950. First, DNA evidence is relevant to identify a person's identity and such evidence is relevant in accordance with section 9 of the Evidence Act 1950. Secondly, since DNA evidence is provided by DNA experts after analysing the samples found in a case, the evidence is also relevant under section 45 of the Evidence Act 1950.

In general, section 45 of the Evidence Act 1950 sets out situations in which the evidence of expert opinion is admissible. The section states as follows:

(1) When the court has to form an opinion upon a point of foreign law or of science or art, or as to identity or genuineness of handwriting or finger impressions, the opinions upon that point of persons specially skilled in that foreign law, science or art, or in questions as to identity or genuineness of handwriting or finger impressions, are relevant facts.

(2) Such persons are called experts.

On the basis of the foregoing section, the court can only obtain the assistance of experts in the fields described in the section. The fields are: foreign law; science or art; handwriting; and finger impression (Raja Muhammad Zuha \& Ramalinggam 2017; Ramalinggam et al. 2012). In contrast, experts from other fields who are not listed in this section cannot be called to give evidence. Thus, in order to allow DNA experts to testify in any case, they must come from the fields provided for in section 45 of the Evidence Act 1950. It appears at a glance that DNA is not in the category because the word "DNA" is not explicitly specified in the section. The provision, however, refers to "science" as one of the categories. Hence, the question may arise as to whether the expression "science" in the section is wide enough to cover DNA. In determining the answer, reference can be made to the case of Chandrasekaran \& Ors V PP [1971] 1 MLJ 153 p.159, where the court held that the expression 'science or art' is elastic enough to be given a liberal interpretation and the fact that the section does not specify particular fields of knowledge does not mean that they are not included. This approach was affirmed in the Federal Court case of Pathmanabhan Nalliannen $v$ Public Prosecutor \& Other Appeals [2017] 4 CLJ 137 p.178 where the court emphasized the following: "With respect, such argument ignores the point that DNA evidence is admissible under s.45, s.46 and s. 51 of the EA. It is basically opinion evidence of an expert." This decision clearly indicates that the Federal Court held that DNA evidence falls under section 45 of the Evidence Act and is therefore admissible in court (Ramalinggam 2017).

\subsection{Is the Court Bound by Expert Evidence?}

In general, the court is not obligated to follow expert evidence but to merely use it to help make the right decision. This principle can be seen in a number of cases. Firstly, the case of Rajagopal $v$ Public Prosecutor [1977] 1 MLJ 6 p.7, in which the Federal Court stated:

As we have already said, the learned judge in fact dealt at great length in his summing-up with the evidence of Dr. Mahadevan, at the end of which he directed the jury that the doctor was only expressing an opinion which they were not bound to follow as the whole question of whether the accused was sane or insane at the time of the commission of the offence was a question which they alone must decide.

The same principle was then applied in the Federal Court case of Wong Swee Chin v Public Prosecutor [1981] 1 MLJ 212 pp. 213- 214, where the court stated:

DW2 was called as an expert witness. Our system of jurisprudence does not, generally speaking, remit the determination of dispute to experts. Some questions are left to the robust good sense of a jury. Others are resolved by the conventional wisdom of a judge sitting alone. In the course of elucidating disputed questions, aids in the form of expert opinions are in appropriate 
cases placed before juries or judges.

Thirdly, in the case of Kulasingam v Thambipillai (1997) 1 MLJ 288, the Kuala Lumpur Court of Appeal explained that "expert witnesses can give his opinion but the court is free to make his own conclusions."

Fourthly, the case of Law Society of India v Fertilizer and Chemicals Travancore Ltd. AIR 1994 Ker 308 p.367 decided that the court had no obligation to blindly accept the expert opinion. This shows that the court is free to accept opinions expressed in the proceedings by an expert on an issue.

The issue was further elaborated in Public Prosecutor v KK [2007] 6 CLJ 367, where a number of legal principles concerning the judgment of expert evidence were laid down by the court. Among them, the duty of expert witnesses is to assist the court in decision-making, the expert witness does not make a decision; the task of decision-making is the responsibility of the court; expert evidence is to assist the court in a judgment and not obligatory to follow; and in making a decision, the judge should evaluate the evidence of all the witnesses, including the expert witness's evidence.

Based on the above-mentioned cases, it is clear that the court is not bound by an expert opinion when deciding on an issue. This situation also shows that the ultimate decision on an issue lies with the judge instead of the expert himself who gives his opinion. This was emphasized by Lord Diplock in the case of R v Lanfear [1968] 2 QB 77 that the evidence of the expert witness should be assessed as evidence from other witnesses. It is a wrong to say that a judge must accept expert evidence.

\subsection{Can the Court Simply Disregard Expert Evidence?}

The next important question is whether or not the court can simply disregard an expert evidence as it is not bound by the expert evidence. This was discussed the case of $R$ v Anderson [1972] 1 QB 304 , where the court explained that "it would be equally a misdirection to tell a jury that it could disregard expert evidence which had been given by only one witness and which, if accepted, dictated one answer."

In this case, it is clear that although the judges are not obliged to accept the evidence presented by an expert witness, the court should not disregard such evidence. The court must form its own opinion on the basis of the expert's evidence.

\subsection{Status of Scientific Expert Evidence}

If the expert evidence is scientific in nature, what is the position of such evidence in court? This principle was underlined in Malaysia in the case of Wong Swee Chin v Public Prosecutor [1981] 1 MLJ 212, in which Judge Raja Azlan Shah at p.14 stated:

But, except on purely scientific issues, expert evidence is to be used by the court for the purpose of assisting rather than compelling the formulation of the ultimate judgments. In the ultimate analysis it is the tribunal of fact, whether it be a judge or jury, which is required to weigh all the evidence and determine the probabilities. It cannot transfer this task to the expert witness, the court must come to its own opinion.

The above quotation clearly shows that when the issue before the judge is scientific in nature, then the evidence given by the experts cannot be disregarded by the court. The court is compelled to accept the expert evidence on DNA as it forms a part of scientific evidence. The court may only disregard the evidence from DNA experts if the experts are not qualified and/or there are rebuttal experts on the same issue. Therefore, it can be generally interpreted that expert evidence can be divided into two i.e. non-scientific evidence and scientific evidence. For the former, expert evidence is not obligatory to follow but merely to help the court in making decisions. Whereas, in respect of the latter, the court is compelled to accept scientific evidence including DNA unless the experts are not qualified and/or there are rebuttal experts on the same issue. 


\subsection{The Probative Value of DNA Evidence in Malaysia}

Although the DNA evidence is given by the experts, its probative value depends on the nature of the evidence itself. DNA science is based on the theory of probability. DNA evidence cannot be treated as conclusive evidence and cannot be used in a criminal case as the sole basis for conviction (Rajesh Gupta 2017). This is well illustrated in the case of Premjibhai Bachubai Kasiya v State of Gujarat, 2009 Cri. L.J. 2888 (Guj.).

The evidence of the DNA experts is in the form of opinion. The DNA experts give opinion evidence on the findings based on the analysis conducted in the laboratory. This is clearly illustrated in section 45 of the Evidence Act 1950 where the provision uses the "opinion of experts" as the heading.

Furthermore, the probative value of the expert evidence was discussed in several cases. Firstly, the case of Public Prosecutor v Samundee Devan Muthu Kerishnan [2006] 3 CLJ 161 p. 173 where the court opined that it is trite law that experts do not decide, the ultimate decision is with the judge. Evidence of the experts is only opinion. It is not conclusive. The expert opinion should be of a corroborative nature to the facts and circumstances of the case. If the expert opinion contradicts an unimpeachable eye witness or documentary evidence, then it will not have an upper hand over direct evidence.

Since DNA evidence is given as an expert opinion, it is neither conclusive nor has a high probative value. The actual probative value of expert opinion on DNA is low as it is not given by a witness of facts. In other words, although the DNA evidence of the accused was found from the crime scene or the body of the victim, it does not mean that the accused would automatically be guilty. DNA evidence should also be viewed with the evidence of other witnesses (if any). In other words, the mere existence of DNA evidence alone cannot link the accused to the crime (Mohd Munzil 2010). If other evidence does not support or is in conflict with the DNA evidence, then the DNA evidence alone is not sufficiently strong to convict the accused. This was discussed in the case of Public Prosecutor v Hanif Basree Abdul Rahman [2008] 4 CLJ 1, where the court had acquitted the accused from the offence charged. One of the grounds for the acquittal was:

The accused's DNA found in circumstances that may have created suspicion of his guilt is not enough to prove his guilt. If there are reasonable explanations as to why his DNA was found in those circumstances, the benefit must be given to him and he must be acquitted and discharged.

This case indicates that the discovery of the accused's DNA profile on the deceased's body per se could not be sufficient to conclude that he had caused her death. This is because the accused had explained that his DNA was in the deceased's body due to sexual intercourse between them before she died. The most important evidence against the prosecution was the presence of a man with a foul body odour in the apartment and the DNA of the "Unknown Male 1" recovered from the body of the deceased, which remained unchallenged. The prosecution's attempt to link the man with the foul body odour with the accused was denied by Noritta's apartment partner, Azora Abdul Hamid, a prosecution witness who testified that the accused had no such body odour. Hence, there was a reasonable likelihood of the existence of another person who could have committed the offence on the night of the incident.

\section{Conclusion}

In brief, expert evidence plays an important role to allow the court to make the right decision (Paul \& Narang 2017). Expert evidence can generally be divided into two forms which are non-scientific evidence and scientific evidence. For non-scientific evidence, the court is not obligated to follow the opinion as the ultimate decision on an issue lies with the judge instead of the expert. However, if the evidence is scientific in nature, then the evidence provided by the experts cannot simply be disregarded by the court because the evidence contains scientific information that is beyond the common knowledge and experience of a judge. The court is obliged to accept scientific evidence, including DNA, because it is a part of scientific evidence unless the experts are not qualified and/or there are rebuttal experts on the same issue. However, it is important to note that DNA evidence is based on the theory of probability. DNA evidence cannot be treated as conclusive evidence but 
must also be viewed in light of other evidence to determine the guilt of the accused.

\section{Acknowledgment}

This research is funded by Universiti Kebangsaan Malaysia (UKM) through research grant i.e. GGPM-2017-019.

\section{References}

\section{Books/ Articles}

Bowers CM, (2014) Forensic Testimony: science, Law and Expert Evidence. Academic Press, United States of America.

Dedrickson K, (2017) Universal DNA databases: a way to improve privacy? Journal of Law and the Biosciences, 4(3), 637.

Fisher, B. A. (2017). A new challenge for expert witnesses relying on subjective information. Forensic sciences research, 2(3), 113.

Gupta R, Gupta S, Gupta M (2016) Journey of DNA Evidence in Legal Arena: An Insight on Its Legal Perspective Worldwide and Highlight on Admissibility in India. Journal of Forensic Science and Medicine, 2(2), 102.

Hunter P, (2010) Anything you touch may be used against you. EMBO reports, 11(6), 424-427.

Ingram, J. L. (2017). Criminal evidence ( $11^{\text {th }}$ ed.). USA; Anderson Publishing.

Jinan Mohamad Pauzi \& Mariani Ariffina (2015) Legal Status of Chemical Fingerprints under Section 45 of Malaysia's Evidence Act 1950. Procedia Environmental Sciences, 30, 349-353.

Magalhães T, Dinis-Oliveira RJ, Silva B, Corte-Real F, Nuno Vieira D (2015) Biological evidence management for DNA analysis in cases of sexual assault. The Scientific World Journal, 2015.

Matheson S, (2016) DNA phenotyping: snapshot of a criminal. Cell, 166(5), 1061-1064.

Mohd Munzil Muhamad (2010) Reliability and Conclusiveness of DNA Evidence in Criminal Trial. Malayan Law Journal, 1 MLJ ciii.

Morsek L, (2000) Get on Board for the Ride of Your Life-The ups, the downs, the Twists, and the Turns of the Applicability of the Gatekeeper Function to Scientific and Non-Scientific Expert Evidence: Kumho's Expansion of Daubert. Akron L. Rev., 34, 689.

Noraini Ibrahim. (2007). Building a credible and believable narrative: The role of direct examination in expert witness testimony. 3L Journal of Language Teaching, Linguistics and Literature, 13.

Paul SR, Narang SK (2017) Expert witness participation in civil and criminal proceedings. Pediatrics, 139(3), e20163862.

Raja Muhammad Zuha Raja Kamal Bashah, Ramalinggam Rajamanickam (2017). Entomologi Forensik sebagai Keterangan Saintifik. The Law Review, 36.

Rajesh Gupta (2017) C.D. Field's A Legal Treatise on Expert Evidence: A Practical Voir Dire (Medical and NonMedical). (5th edtn), Delhi Law House, Delhi.

Ramalinggam Rajamanickam (2017) Skop Seksyen 45 Akta Keterangan 1950: Keperluan Untuk Semakan Semula. Jurnal Undang-Undang dan Masyarakat, 21(2).

Ramalinggam Rajamanickam et al. The Position of Similar Fact Evidence in Malaysia. Mediterranean Journal of Social Sciences, [S.I.], v. 6, n. 4, p. 539, jul. 2015.

Ramalinggam Rajamanickam, Anita Abdul Rahim, Anisah Che Ngah (2012) Kerelevanan Keterangan Pakar Forensik di bawah Seksyen 45 Akta Keterangan 1950. The Law Review, 414.

Ramalinggam Rajamanickam; Anita Abdul Rahim. The Position of Psychological Expert Evidence under the Malaysian Evidence Act 1950. Mediterranean Journal of Social Sciences, [S.I.], v. 5, n. 14, p. 128, jul. 2014.

Shaler RC (2011) Crime scene forensics: A scientific method approach. Taylor \& Francis, Boca Raton.

Wheatcroft, J. M., \& Ellison, L. E. (2012). Evidence in Court: Witness Preparation and Cross-Examination Style Effects on Adult Witness Accuracy. Behavioral sciences \& the law, 30(6), 821-840.

\section{Case law}

Chandrasekaran \& Ors v PP [1971] 1 MLJ 153.

Kulasingam $v$ Thambipillai (1997) 1 MLJ 288.

Law Society of India v Fertilizer and Chemicals Travancore Ltd. AIR 1994 Ker 308.

Pathmanabhan Nalliannen v Public Prosecutor \& Other Appeals [2017] 4 CLJ 137.

Premjibhai Bachubai Kasiya v State of Gujarat, 2009 Cri. L.J. 2888 (Guj.). 
Public Prosecutor v Hanif Basree Abdul Rahman [2008] 4 CLJ 1.

Public Prosecutor v KK [2007] 6 CLJ 367.

Public Prosecutor v Samundee Devan Muthu Kerishnan [2006] 3 CLJ 161.

$R$ v Anderson [1972] 1 QB 304.

R v Lanfear [1968] 2 QB 77.

Rajagopal v Public Prosecutor [1977] 1 MLJ 6.

Wong Swee Chin v Public Prosecutor [1981] 1 MLJ 212.

\section{Dictionary}

Garner BA (2014) Black's Law Dictionary. (10 ${ }^{\text {th }}$ edtn), Thomson Reuters, United States of America. Martin EA (1994) A Dictionary of Law. Oxford University Press, Oxford. 